\title{
Investigation of BSA adsorption performances of metal ion attached mineral particles embedded cryogel discs
}

\author{
Ömür Acet \\ Vocational School of Health Science, Pharmacy Services Program, Tarsus University, Tarsus, Turkey, \\ omuracet@tarsus.edu.tr, ORCID: 0000-0003-1864-5694
}

\begin{abstract}
A B S T R A C T
Blood plasma is rich in albumin protein. Albumin has some physiological duties. Investigations over separation of albumin has been paid considerable interest for its excellent potential in blood protein production. Natural pumice particles are non-toxic, reasonably priced and alternative adsorbents with excellent adsorption performance. In order to study the adsorption performance of BSA on composite cryogel discs with immobilized metal affinity chromatography (IMAC), $\mathrm{Cu}^{+2}$-attached natural pumice particles were designed and they were embedded into cryogel generated medium. $\mathrm{Cu}^{2+}$-attached natural pumice particle embedded composite cryogel discs $\left(\mathrm{Cu}^{2+}\right.$-NP-ECDs) were synthesized through polymerization of gel-former factors at minus temperatures. The characterization experiments of the $\mathrm{Cu}^{2+}$-NP-ECDs were accomplished via SEM, FTIR experiments. The experiments were studied in a batch system. The highest amount of adsorbed BSA (356,8 mg/g particles) onto discs was obtained at pH 7.0 (phosphate buffer), $4 \mathrm{mg} / \mathrm{mL}$ concentration of BSA. As a result of conducted 30 adsorption-desorption experiments periods, there was no important change in adsorption performance of composite discs.
\end{abstract}

\section{ARTICLE INFO \\ Research article}

Received: 20.02.2021

Accepted: 02.04.2021

Keywords:

IMAC,

cryogel disc, pumice particle, bovine serum albumin, adsorption

${ }^{*}$ Corresponding author

\section{Introduction}

Lately, protein adsorption studies have become so widespread since it has been having very many practices in science of biological [1, 2, 3]. Blood plasma is rich in albumin protein [4]. It can deliver most drugs to target organs or cells where therapeutic missions are exerted [5, 6, 7]. Bovine serum albumin (BSA) is a globular blood plasma protein that fulfills as the stabilizator of enzymes [8]. The studies on the BSA separation has been paid much attention for its excellent potential by researchers.

Immobilized metal affinity chromatography (IMAC) presented by Porath et al. (1975) has turned into a common analytic and preparative separation technique on purification of some biomolecules [9, 10,11, 12, 13]. Proteins with standard of high purity, which are extensively utilized in various fields, such as molecular biology and biotechnology, can be gained through His-tagged recombinant proteins which require IMAC $[14,10]$.

Cryogels are sub-category of hydrogels, which are biomaterials with excellent physical properties [15]. They have spongy morphologies with inter-connected macroporous, elastic structures and high mechanical robustness [16]. They are multi-purpose tools that could be turn to good purpose intended practices [17], such as purification and adsorption of some biomolecules [18, 19, 9], removal of heavy metals, dyes, $[20,21]$ and water treatment process [22]. The boosting of cryogel properties will carry forward its potential usage in various areas [17]. The weak side of cryogels that adsorption capacities of them for proteins is not at intended levels since the low surface area of inter-connected supermacropores within the matrix [23, 24, 25]. Enhancing the binding performance of cryogels has a great significance in bioseparation operations [26].

Some composite materials have been conducted to fulfill some important duties [27, 28].Natural particles (i.e., pumice particles) can be embedded in the cryogel structure to solve the problem of low surface area and achieve high efficiency in a short time. These composite polymers can be successfully applied in protein adsorption studies. Particle embedded cryogels are a special kind of cryogels column to widen the surface area owing to the unification of the unique features of both cryogels and particles. Pumice particles are natural adsorbents and have some advantages such as low cost, nontoxicity and high surface area for superior adsorption potential. [13, 29]. 
Here, $\mathrm{Cu}^{2+}{ }_{-}$NP-ECDs were developed a new type of functional, low cost, composite cryogel disc for adsorption of BSA. Effects of pH, initial BSA concentration, ionic strength and temperature on BSA adsorption onto the $\mathrm{Cu}^{2+}$-NP-ECDs were studied. Prepared composite cryogel disc and pristine cryogel disc were analysed with some characterizations concerning Fourier Transform Infrared Spectrophotometer (FTIR), Scanning Electron Microscopy (SEM), and attached amount of $\mathrm{Cu}^{2+}$ ions.

\section{Materials and methods}

\subsection{Materials}

The pumice particles were obtained from Pumice Research Centre (through Dr. Fatma Gurbuz), Süleyman Demirel University. 2-Hydroxyethyl methacrylate (HEMA) was provided from Fluka A.G (Buchs, Switzerland). $N, N$ 'methylene-bis-acrylamide (MBAAm), $\quad N, N, N^{\prime}, N^{\prime}$ Tetramethylethylene-diamine (TEMED) and ammonium persulfate (APS) were purchased by Sigma (St. Louis, MO, USA). Other chemicals were purcahed at reagent grade from Merck AG (Darmstadt, Germany).

\subsection{Preparation of natural pumice particles (NP)}

Natural pumice particles have been occurred by pre-treatment to remove substances that may be extracted and affected the surface area of natural particles. For this purpose, the pumice particles were put into acid (3.0 M HCl) and alkali (3.0 M $\mathrm{NaOH}$ ) solutions for 24 hours. And also, a heating method was conducted at $130{ }^{\circ} \mathrm{C}$ for $5 \mathrm{~h}$ for the removal of organic contaminants from the pore structures. Therefore, the surface area of natural particles has been enlarged. The treated particles were washed by using distilled water and dehydrated at $180^{\circ} \mathrm{C}$ for 24 hours.

\subsection{Attachment of $\mathrm{Cu}^{2+}$ ions to natural pumice particles $\left(\mathrm{Cu}^{2+}{ }_{-}\right.$ NP)}

Attachment process of $\mathrm{Cu}^{2+}$ ions to NP was operated (at room temperature, $2 \mathrm{~h}$ ) with a $\mathrm{Cu}^{2+}$ ions containing solution (100 ppm, pH 5.0 tuned up with $0.01 \mathrm{M} \mathrm{HCl}$ ). The quantity of binded $\mathrm{Cu}^{2+}$ ions onto NPs were calculated through beginning and last solutions of $\mathrm{Cu}^{2+}$ ion by a graphite furnace atomic absorption spectrometer (GFAAS, Analyst 800/PerkinElmer, Waltham, MA).

2.4 Formation of $\mathrm{Cu}^{2+}$-attached natural pumice particle embedded composite cryogel disc $\left(\mathrm{Cu}^{2+}-\mathrm{NP}-\mathrm{ECD}\right)$

HEMA (6 mmol) as monomer and MMBAm $(1 \mathrm{mmol})$ as cross-linker were dissolved in deionized water $(14 \mathrm{~mL})$ by cryo-polymerization method. Then, $150 \mathrm{mg} \mathrm{Cu}{ }^{2+}-\mathrm{NP}$ was added into polymerization solution, APS $(10 \%, \mathrm{w} / \mathrm{v})$ as the free radical producer and TEMED $(20 \mu \mathrm{L})$ as the initiator were added immediately. The prepared solution was poured into two glass layers (separated by $1.5 \mathrm{~mm}$ thick spacers) and was completed the polymerization in the refrigerator frozen at -12 ${ }^{\circ} \mathrm{C}$ for $24 \mathrm{~h}$. After polymerization, it was thawed at room temperature. The synthesized composite cryogel discs were washed with deionized water until the impurities were removed. They were cut into circular discs $(0.6 \mathrm{~cm}$ in diameter) with the help of a perforator. Lastly, they were put into buffer containing sodium azide $(0.02 \%)$ at $4{ }^{\circ} \mathrm{C}$ until usage.

\subsection{Characterization of $\mathrm{Cu}^{2+}-\mathrm{NP}-\mathrm{ECD}$ sample and pristine cryogel}

The functional groups of $\mathrm{Cu}^{2+}-\mathrm{NP}-\mathrm{ECD}$ and natural pumice were brightened by Fourier Transform Infrared Spectrometer (FTIR 8000 Series, Shimadzu, Japan). These samples (about $0.1 \mathrm{~g}$ ) were combined separately with $\mathrm{KBr}$. They were pelleted and analyzed by FTIR spectrophotometer.

The surface structure of pristine cryogel and $\mathrm{Cu}^{2+}$-NP-ECD membrane discs were examined by using scanning electron microscopy (SEM, EVO LS 10 ZEISS 5600 SEM, Tokyo, Japan) at desired magnifications. For this purpose, the composite discs and pristine discs were swollen in deionized water. Then, they were put into absolute (98\%) ethanol to replace water with alcohol molecules in the pores. Immediately after the alcohol is diffused, both samples were put into an oven $\left(60^{\circ} \mathrm{C}\right)$ to remove the alcohol molecules from the samples without harm their structures. The dewatered samples were coated with gold-palladium (40:60) and they were then taken to SEM for taking images.

\subsection{Adsorption-elution stages of BSA from aqueous solutions}

BSA adsorption experiments on composite cryogel discs were applied in a shaker bath system to investigate some parameters such as $\mathrm{pH}$ effect, initial BSA concentration, ionic strength effect and temperature factor. The control of temperature on the shaker system was followed with temperature control unit of shaker. The phosphate buffer $(\mathrm{pH} 7.0,0.05 \mathrm{M})$ was implemented to equilibrate the system. All BSA readings were accomplished at $280 \mathrm{~nm}$ via a UV spectrophotometer (Shimadzu, Tokyo, Japan, Model 1601). Elution of adsorbed BSA from $\mathrm{Cu}^{2+}$-NP-ECDs were accomplished with $0.5 \mathrm{M}$ $\mathrm{NaCl}$ solution .

\section{Results and discussion}

\subsection{Characterization of $\mathrm{Cu}^{2+}-\mathrm{NP}-\mathrm{ECD}$ sample and pristine cryogel}

The quantity of $\mathrm{Cu}^{2+}$ ions binded to natural pumice particles was determined to be $40 \mathrm{mg} / \mathrm{g}$. Additionally, It was checked for any ion leakage. No ion leakage was found. This outcome approved that washing process was satisfying.

The FTIR spectra of both natural pumice particles and pumice particle embedded cryogel discs were shown in Figure 1. $\mathrm{SiO}_{2}$ 
is found in natural pumice particles about $70 \%$ percentage [29]. The typical $\mathrm{SiO}_{2}$ stretching vibration band of about was observed around $1006 \mathrm{~cm}^{-1}$. On the other hand, the wavelength belonged to the $\mathrm{SiO}_{2}$ groups in pumice particle embedded cryogel disc shifted to around $1022 \mathrm{~cm}^{-1}$. The shift value in FTIR spectrum of natural pumice particle embedded cryogel discs can be attributed to the interaction of the $\mathrm{Cu}^{2+}{ }_{-} \mathrm{NP}$ with the cryogel structure and the presence of the $\mathrm{Cu}^{2+}-\mathrm{NP}$ in the cryogel disc structure.

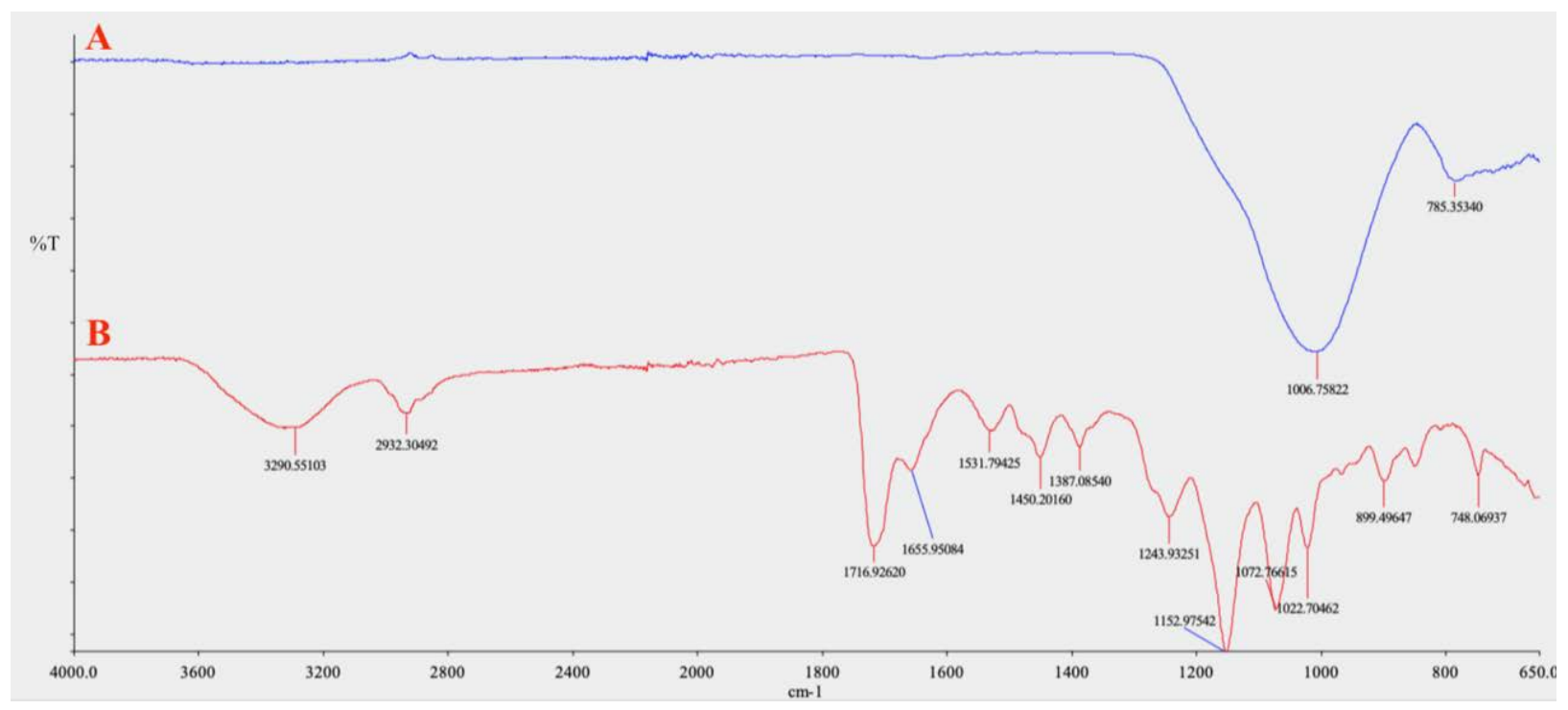

Figure 1. FTIR spectra: Natural pumice (A) and $\mathrm{Cu}^{2+}-\mathrm{NP}-\mathrm{ECDs}$ (B).

The structures of pristine cryogel discs and $\mathrm{Cu}^{2+}$-NP-ECDs were portrayed by a scanning electron microscope to figured out surface structures in Figure 2. Even if pristine cryogel discs have perfect flow rate and unique interconnected routes, they have insufficient adsorption capacity in consequence of their low surface area. $\mathrm{Cu}^{2+}$-NPs were combined with cryogel disc structures to cope with this problem of them. $\mathrm{Cu}^{2+}-\mathrm{NP}-$ ECDs have highly porous and spongy morphologies as a result of uniformly dispersing of $\mathrm{Cu}^{2+}$-NPs into cryogel discs. Therefore, this integrated morphological construction that high surface area fulfilled for circulation of mobile phase, enhanced the adsorption performance owing to the unification of these binary structure. $\mathrm{Cu}^{2+}$-NP-ECDs displayed excellent BSA adsorption (mg/g) with respect to the adsorption capacity of pristine cryogel discs (mg/g).

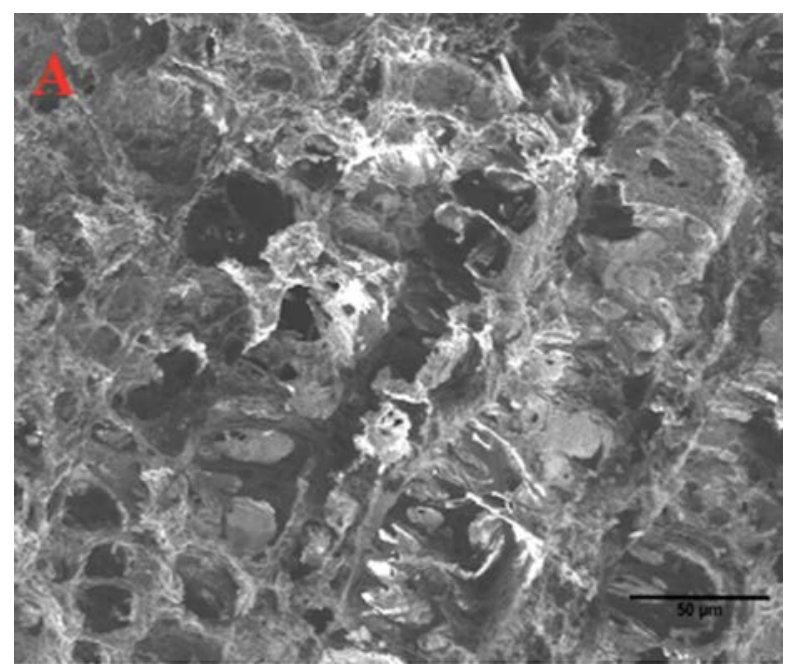




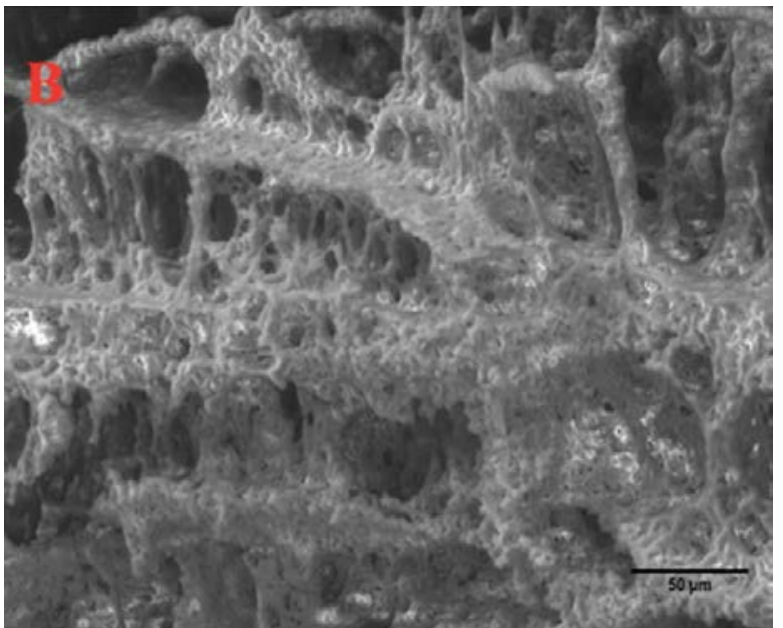

Figure 2. SEM images of pristine cryogel discs (A) and $\mathrm{Cu}^{2+}$ NP-ECDs (B).

\subsection{Effect of $p H$ on BSA adsorption}

Figure 3 indicates the effect of $\mathrm{pH}$ parameter on BSA adsorption. In all the occasions studied, the highest adsorption of BSA was observed at $\mathrm{pH}$ 7.0. Low adsorption was observed for acidic and alkaline $\mathrm{pH}$ regions with composite discs. The decrease in the BSA adsorption performance was seen in these regions because of electrostatic repulsion impacts between the opposite charged groups. The isoelectric $\mathrm{pH}$ of BSA is in the range of 4.7-5 in the literature [28]. Here, the highest adsorption was obtained at $\mathrm{pH}$ 7.0. Especially, the affinity between $\mathrm{Cu}^{+2}$ ions on natural pumice particles and BSA molecules (in particular, imidazole (histidine), thiol (cysteine), and indoyl (tryptophan)) are mainly responsible for the specific or electron donor-acceptor interactions. These specific interactions are based on the event of deprotonation of amino acid side changings (i.e., histidine and in particular primary amines such as lysine) of BSA with immobilized $\mathrm{Cu}^{+2}$ ions. The changings as conformational because of the specific interactions of BSA molecules at this $\mathrm{pH}$ point may also cause specific interaction [29].

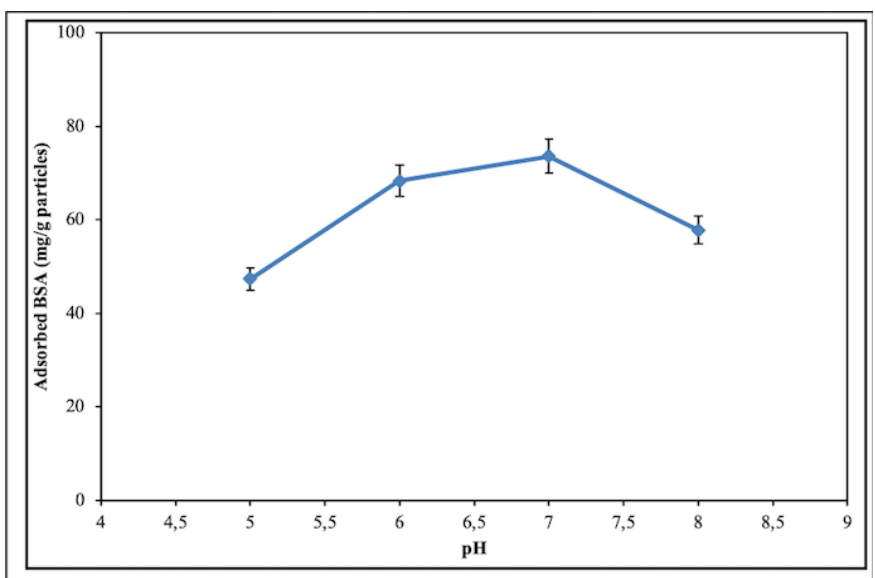

Figure 3. Effect of pH on adsorption of BSA. ( CBSA $1 \mathrm{mg} / \mathrm{mL}, \mathrm{T}: 25$ ${ }^{\circ} \mathrm{C}$ )

\subsection{Effect of initial BSA concentration}

The particles of natural origin with non-toxic, modifiable properties are attractive for biomedical applications. [30, 31]. The effect of initial concentration of BSA over adsorption have been shown in Figure 4. Different BSA concentrations $(0.25-4 \mathrm{mg} / \mathrm{mL})$ were conducted to investigate effect of initial BSA concentration on adsorption onto $\mathrm{Cu}^{2+}$-NP-ECDs. Even though the adsorption of BSA pristine cryogel discs' having low adsorption performance, the power of adsorption capacity of $\mathrm{Cu}^{2+}$-NP-ECDs were reasonably satisfactory (356,8 mg/g particles).

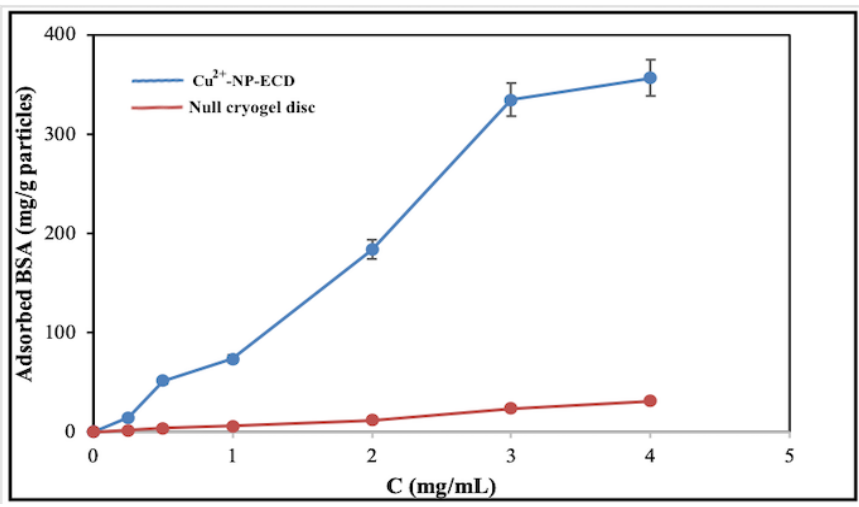

Figure 4. The effect of initial BSA concentration on adsorption. $(\mathrm{pH}$ 7.0, T: $25^{\circ} \mathrm{C}$ )

The maximum adsorption capacity was obtained at $4 \mathrm{mg} / \mathrm{mL}$. The binding sites on the $\mathrm{Cu}^{2+}$-NP-ECDs for BSA were satiated. No significant increase in amount on adsorption seen after the BSA concentration of $4 \mathrm{mg} / \mathrm{mL}$. This event can be emphasized by feeding of interaction regions on the cryogel disc occupied by BSA molecules. Consequently, $\mathrm{Cu}^{2+}-\mathrm{NP}-$ ECD cryogel discs obtained a high adsorption of $356,8 \mathrm{mg} / \mathrm{g}$ particles. However, pristine cryogel discs achieved just 31,4 $\mathrm{mg} / \mathrm{g}$ particles.

\subsection{Effect of ionic strength}

The effect of ionic strength on BSA adsorption also investigated at various concentrations $(0-0.5 \mathrm{M})$ ( Figure 5). As demonstrated in Figure 5, it was observed a diminish in adsorption versus boosting ionic strength. This situation is able to described as follows: The increase in salt concentration prevented the electrostatic interactions between the ligand and BSA as a result of masking the groups interacting on the adsorbent. 


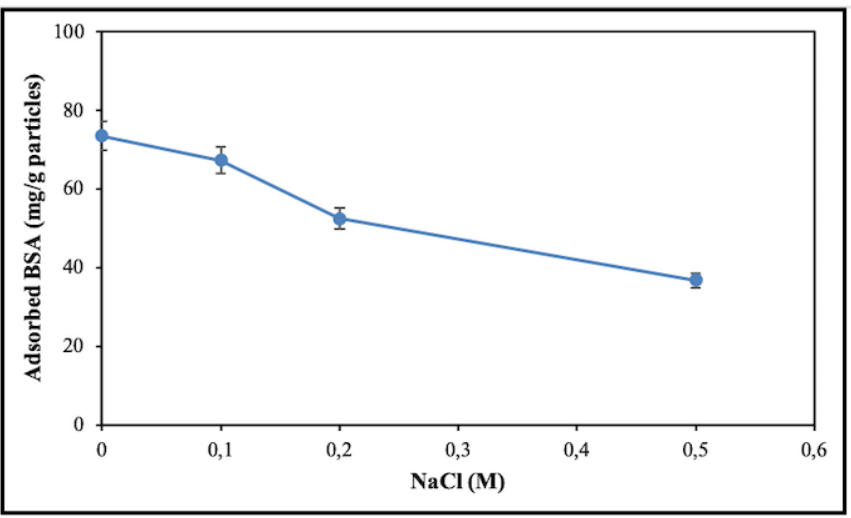

Figure 5. The effect of ionic strength on adsorption of BSA. (pH

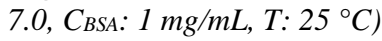

The effect of temperature gives important information over adsorption of biomolecules on a adsorbent surface. The temperature parameter was carried out in the range of 5$35^{\circ} \mathrm{C}$. As demonstrated in Figure 6, the adsorption of BSA onto $\mathrm{Cu}^{2+}$-NP-ECDs enhanced up to $25^{\circ} \mathrm{C}$, immediately after the adsorption was started to fall after $25^{\circ} \mathrm{C}$. This condition can be expressed with electrostatic interaction dominance between BSA molecules and $\mathrm{Cu}^{2+}$-NP-ECDs.

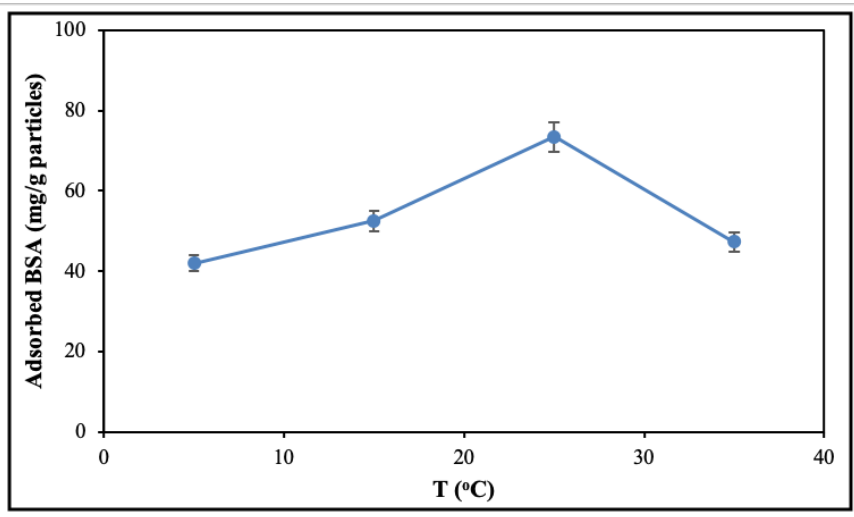

Figure 6. The effect of temperature on adsorption of BSA. ( $p H$ 7.0, CBSA: $1 \mathrm{mg} / \mathrm{mL}$ )

The reusability of $\mathrm{Cu}^{2+}$-NP-ECD composite cryogel discs presented satisfactory performance. Here, over 95\% of adsorbed BSA was desorbed by $0.5 \mathrm{M} \mathrm{NaCl}$. Adsorptiondesorption stages were iterated 30 times by operating the same disc, and a considerable changing wasn't seen in cryogel disc structure.

\section{Conclusion}

In sum, $\mathrm{Cu}^{2+}$-NP-ECDs were synthesized to study the adsorption capacity for BSA from aqueous solution. The highest adsorption value was obtained at pH 7.0 as $356,8 \mathrm{mg} / \mathrm{g}$ particles. The reusability experiments were endorsed 30 adsorption-desorption periods with $0.5 \mathrm{M} \mathrm{NaCl}$ by taking advantage of the same disc. The reusability of $\mathrm{Cu}^{2+}$-NP-ECDs were extremely convenient to use for the next studies. The natural pumice particles and composite cryogel disc were characterized by SEM, FT-IR experiments. Under the light of all performed studies, it is expected that $\mathrm{Cu}^{2+}$-NP-ECDs could be usefully applied for high amount separation of BSA molecules in the field of biomedicine and biotechnology.

\section{Acknowledgements}

The author would like to thank Prof. Dr. Fatma Gürbüz for supplying of natural pumice particles.

\section{References}

[1]. Hinderliter, Anne, Sylvio May., "Cooperative adsorption of proteins onto lipid membranes”, Journal of Physics: Condensed Matter 18 (28), (2006), S1257.

[2]. Horbett, T. A., Brash, J. L., "Proteins at interfaces II", Washington, DC: American Chemical Society, 1995, 580 .

[3]. Rauf, T. A., Anirudhan, T. S., "Synthesis and characterization of sulphonic acid ligand immobilized Aminopropyl silanetriol copolymer and evaluation of its Bovine serum albumin adsorption efficiency”, Materials Today: Proceedings, (2020).

[4]. Zhang, J., Zhang, Z., Song, Y., Cai, H., "Bovine serum albumin (BSA) adsorption with Cibacron Blue F3GA attached chitosan microspheres”, Reactive and Functional Polymers, 66(9), (2006), 916-923.

[5]. Ràfols, C., Zarza, S., Bosch, E. "Molecular interactions between some non-steroidal anti-inflammatory drugs (NSAID's) and bovine (BSA) or human (HSA) serum albumin estimated by means of isothermal titration calorimetry (ITC) and frontal analysis capillary electrophoresis (FA/CE)”, Talanta, 130, (2014), 241250.

[6]. Hage, D. S., "Affinity chromatography: a review of clinical applications”, Clinical chemistry, 45(5), (1999), 593-615.

[7]. Bourassa, P., Kanakis, C. D., Tarantilis, P., Pollissiou, M. G., Tajmir-Riahi, H. A., "Resveratrol, genistein, and curcumin bind bovine serum albümin", The Journal of Physical Chemistry B, 114(9), (2010), 3348-3354.

[8]. Shah, M. T., Alveroglu, E., "Facile synthesis of nanogels modified Fe3O4@ Ag NPs for the efficient adsorption of bovine \& human serum albümin”, 
Materials Science and Engineering: C, 118, (2021), 111390.

[9]. Acet, Ö., Aksoy, N. H., Erdönmez, D., Odabaş1, M., "Determination of some adsorption and kinetic parameters of $\alpha$-amylase onto $\mathrm{Cu}+2$-PHEMA beads embedded column”, Artificial cells, nanomedicine, and biotechnology, 46(sup3), (2018), S538-S545.

[10]. Acet, Ö., Menteş, A., Odabaş1, M., "Assessment of a new dual effective combo polymer structure for separation of lysozyme from hen egg white", Polymer Bulletin, (2019), 1-17.

[11]. Serinbaş, A., Önal, B., Acet, Ö., Özdemir, N., Dzmitruk, V., Halets-Bui, I., Shcharbin, D., Odabaşı, M. "A new application of inorganic sorbent for biomolecules: IMAC practice of Fe3+-nano flowers for DNA separation”, Materials Science and Engineering: C, 113, (2020), 111020.

[12]. Önal, B., Acet, Ö., Sanz, R., Sanz-Pérez, E. S., Erdönmez, D., Odabaşı, M. " Co-evaluation of interaction parameters of genomic and plasmid DNA for a new chromatographic medium”, International journal of biological macromolecules, 141, (2019), 1183-1190.

[13]. Alacabey, İ., Acet, Ö., Önal, B., Dikici, E., Karakoç, V., Gürbüz, F., Alkan, H., Odabaşı, M., "Pumice particle interface: a case study for immunoglobulin G purification”, Polymer Bulletin, (2020), 1-15.

[14]. Li, S., Yang, K., Liu, L., Zhao, B., Chen, Y., Li, X., Zhang, L., Zhang, Y. (2018). "Surface sieving coordinated IMAC material for purification of Histagged proteins”, Analytica chimica acta, 997, 9-15.

[15]. Rezaeeyazdi, M., Colombani, T., Memic, A., Bencherif, S. A., “ Injectable hyaluronic acid-co-gelatin cryogels for tissue-engineering applications”, Materials, 11(8), (2018),1374.

[16]. Hixon, K. R., Lu, T., Sell, S. A., “A comprehensive review of cryogels and their roles in tissue engineering applications”, Acta biomaterialia, 62, (2017), 29-41.

[17]. Eggermont, L. J., Rogers, Z. J., Colombani, T., Memic, A., Bencherif, S. A. "Injectable cryogels for biomedical applications", Trends in biotechnology, 38(4), (2020), 418-431.
[18]. Önal, B., Odabaşı, M., "Design and application of a newly generated bio/synthetic cryogel column for DNA capturing”, Polymer Bulletin, (2020), 1-18.

[19]. Ceylan, Ş., Odabaşı, M., "Novel adsorbent for DNA adsorption: Fe3+-attached sporopollenin particles embedded composite cryogels", Artificial cells, nanomedicine, and biotechnology, 41(6), (2013), 376383.

[20]. Huseynli, S., Bakhshpour, M., Qureshi, T., Andac, M., Denizli, A., "Composite polymeric cryogel cartridges for selective removal of cadmium ions from aqueous solutions”, Polymers, 12(5), (2020), 1149.

[21]. Gurbuz, F., Ozcan, A., Çiftçi, H., Acet, O., Odabasi, M., "Treatment of textile effluents through biocomposite column: Decolorization and COD reduction”, International Journal of Environmental Science and Technology, 16(12), (2019), 8653-8662.

[22]. Gurbuz, F., Akpınar, Ş., Ozcan, S., Acet, Ö., Odabaşı, M., "Reducing arsenic and groundwater contaminants down to safe level for drinking purposes via Fe 3+attached hybrid column”, Environmental monitoring and assessment, 191(12), (2019), 1-14.

[23]. Persson, P., Baybak, O., Plieva, F., Galaev, I. Y., Mattiasson, B., Nilsson, B., Axelsson, A., "Characterization of a continuous supermacroporous monolithic matrix for chromatographic separation of large bioparticles”, Biotechnology and bioengineering, 88(2), (2004), 224-236.

[24]. Ünlü, N., Ceylan, Ş., Erzengin, M., \& Odabaşı, M., "Investigation of protein adsorption performance of $\mathrm{Ni} 2+$-attached diatomite particles embedded in composite monolithic cryogels", Journal of separation science, 34(16-17), (2011), 2173-2180.

[25]. Bereli, N., Şener, G., Altıntaş, E. B., Yavuz, H., Denizli, A., "Poly (glycidyl methacrylate) beads embedded cryogels for pseudo-specific affinity depletion of albumin and immunoglobulin G”, Materials Science and Engineering: C, 30(2), (2010), 323-329.

[26]. Yao, K., Yun, J., Shen, S., Wang, L., He, X., Yu, X., "Characterization of a novel continuous supermacroporous monolithic cryogel embedded with nanoparticles for protein chromatography”, Journal of Chromatography A, 1109(1), (2006), 103-110. 
[27]. Sahiner, N., Karakoyun, N., Alpaslan, D., Aktas, N., "Biochar-embedded soft hydrogel and their use in Ag nanoparticle preparation and reduction of 4-nitro phenol”, International Journal of Polymeric Materials and Polymeric Biomaterials, 62(11), (2013), 590-595.

[28]. Ajmal, M., Demirci, S., Siddiq, M., Aktas, N., Sahiner, N., "Simultaneous catalytic degradation/reduction of multiple organic compounds by modifiable $\mathrm{p}$ (methacrylic acid-co-acrylonitrile)-M (M: Cu, Co) microgel catalyst composites", New Journal of Chemistry, 40(2), (2016), 1485-1496.

[29]. Gurbuz, F., Ceylan, Ş., Odabaşı, M., Codd, G. A., "Hepatotoxic microcystin removal using pumice embedded monolithic composite cryogel as an alternative water treatment method”, Water research, 90, (2016), 337-343.

[30]. Wang, X., Herting, G., Wallinder, I. O., Blomberg, E., "Adsorption of bovine serum albumin on silver surfaces enhances the release of silver at pH neutral conditions ”, Physical Chemistry Chemical Physics, 17(28), (2015), 18524-18534.

[31]. Odabašı, M., Uzun, L., Denizli, A., "Porous magnetic chelator support for albumin adsorption by immobilized metal affinity separation”, Journal of applied polymer science, 93(5), (2004), 2501-2510.

[32]. Sahiner, N., Sagbas, S., Aktas, N., "Preparation of macro-, micro-, and nano-sized poly (Tannic acid) particles with controllable degradability and multiple biomedical uses”, Polymer degradation and stability, (2016), 129, 96-105.

[33]. Sagbas, S., Aktas, N., Sahiner, N., "Modified biofunctional p (tannic acid) microgels and their antimicrobial activity”, Applied Surface Science, 354, (2015), 306-313. 